\title{
Greenhouse Thrips, Heliothrips haemorrhoidalis (Bouche) $^{1}$
}

\section{H. A. Denmark and T. R. Fasulo ${ }^{2}$ \\ Introduction}

This thrips was described by Bouché in 1833 from specimens taken from a greenhouse in Europe as Thrips haemorrhoidalis. Packard described this species for the first time from this country in 1870 and called it the greenhouse thrips. This thrips appears in the Common Names of Insects approved by the Entomological Society of America as the greenhouse thrips, Heliothrips haemorrhoidalis (Bouché).

\section{Synonymy}

Thrips haemorrhoidalis Bouché 1833.

\section{Distribution}

This is a New World species although it was described originally from Europe. It was probably introduced into Europe on ornamental plants from tropical America. It is found on wild and cultivated plants in Brazil, the West Indies, and Central America. It occurs in the United States outdoors in central and southern Florida and southern California.

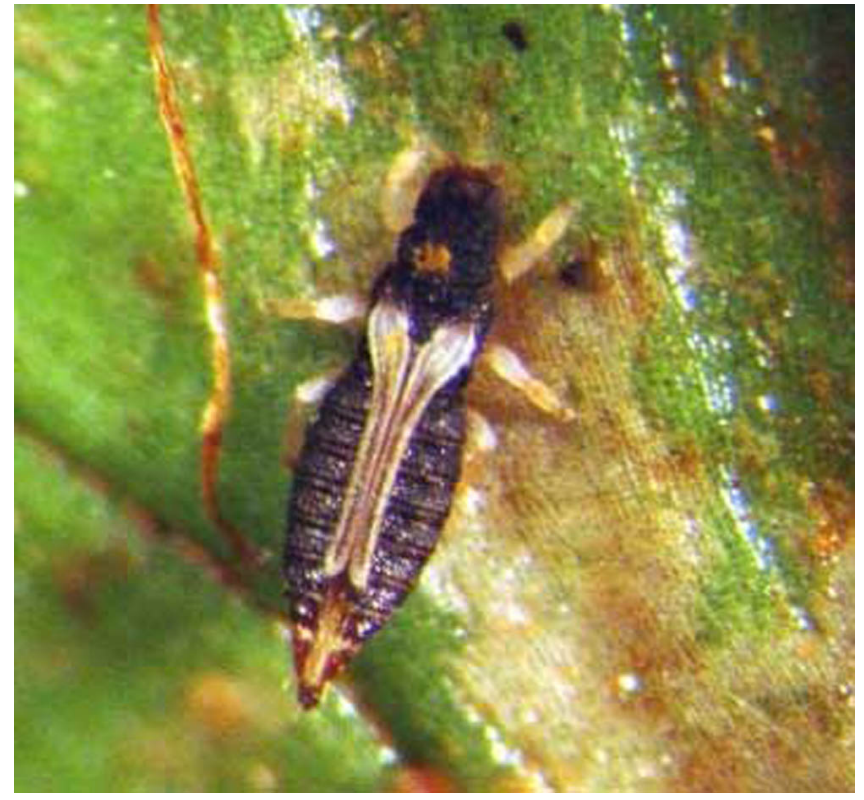

Figure 1. Adult greenhouse thrips, Heliothrips haemorrhoidalis (Bouché). Credits: Mike Merchant, Texas Cooperative Extension Service

It is found in greenhouses throughout the United States. Sometimes it escapes from greenhouses in warm months in states north of Florida. In Europe, it is found in Germany, England, France, Italy, Vienna,

1. This document is EENY-075 (originally published as DPI Entomology Circular No. 64), one of a series of Featured Creatures from the Entomology and Nematology Department, Florida Cooperative Extension Service, Institute of Food and Agricultural Sciences, University of Florida. Published: February 1999. Revised: August 2004. This document is also available on Featured Creatures Website at http://creatures.ifas.ufl.edu. Please visit the EDIS Website at http://edis.ifas.ufl.edu.

2. H. A. Denmark, Florida Department of Agriculture and Consumer Services, Division of Plant Industry, and T. R. Fasulo, Department of Entomology and Nematology, University of Florida, Gainesville, Florida.

The Institute of Food and Agricultural Sciences (IFAS) is an Equal Opportunity Institution authorized to provide research, educational information and other services only to individuals and institutions that function with non-discrimination with respect to race, creed, color, religion, age, disability, sex, sexual orientation, marital status, national origin, political opinions or affiliations. U.S. Department of Agriculture, Cooperative Extension Service, University of Florida, IFAS, Florida A. \& M. University Cooperative Extension Program, and Boards of County Commissioners Cooperating. Larry Arrington, Dean 
Finland, Palestine, and North Africa. This thrips can probably be found over much of the world due to its habits of living in greenhouses. It is a poor flier and remains in the shaded areas on the plant almost all the time.

\section{Description and Biology}

The eggs are white and banana-shaped and are inserted singly in plant tissue. The tip is usually visible with the aid of a hand lens. The early larval stage is whitish with red eyes. Larvae become yellowish after feeding. Mature larvae average about $1 \mathrm{~mm}$ in length. There are two larval instars and then it moults to the prepupal stage which is light yellow with red eyes and short wing pads. The pupal stage is slightly larger, with longer wing pads and larger eyes. It is yellowish and then darkens with age. The antennae are bent backward over the head in the pupal stage. The prepupal and pupal stages do not feed.

The adult's head and thorax darken to black while the abdomen changes from yellow, yellow-red, brown, and black. Cool temperatures retard the color changes. The legs remain a light yellow, and the antenna has eight segments. The greenhouse thrips is parthenogenic, in that it reproduces without mating, and males are seldom seen. The adult females insert their eggs into the leaf or fruit surface. Just before hatching the egg blisters. If a hand lens is used, this helps somewhat in surveying for emerging populations as it shows where the eggs are in the leaves (Anonymous 2003).

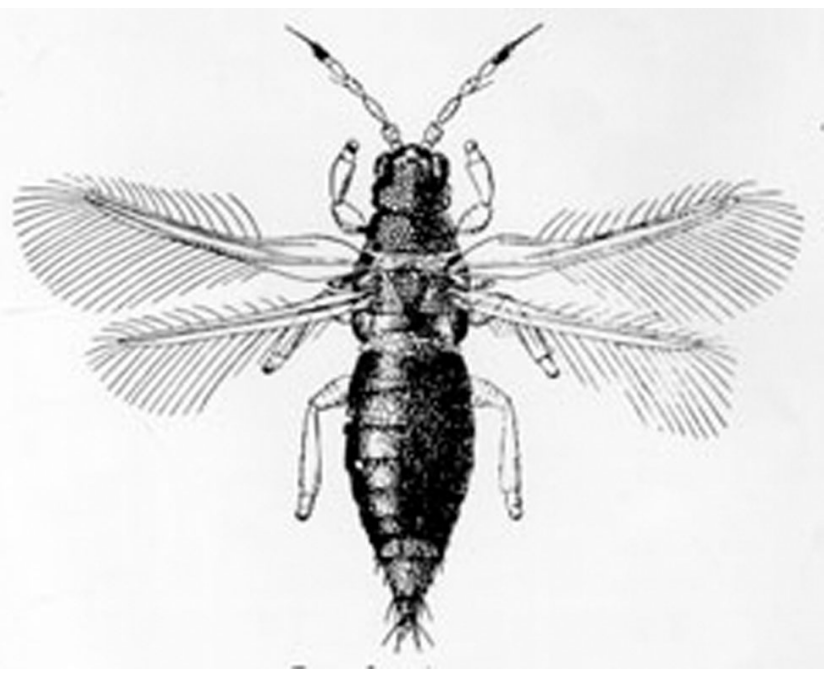

Figure 2. Adult. Credits: Division of Plant Industry

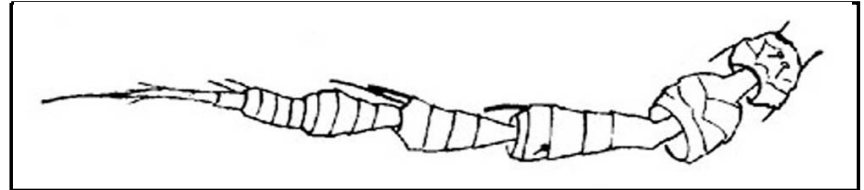

Figure 3. Antenna. Credits: Division of Plant Industry

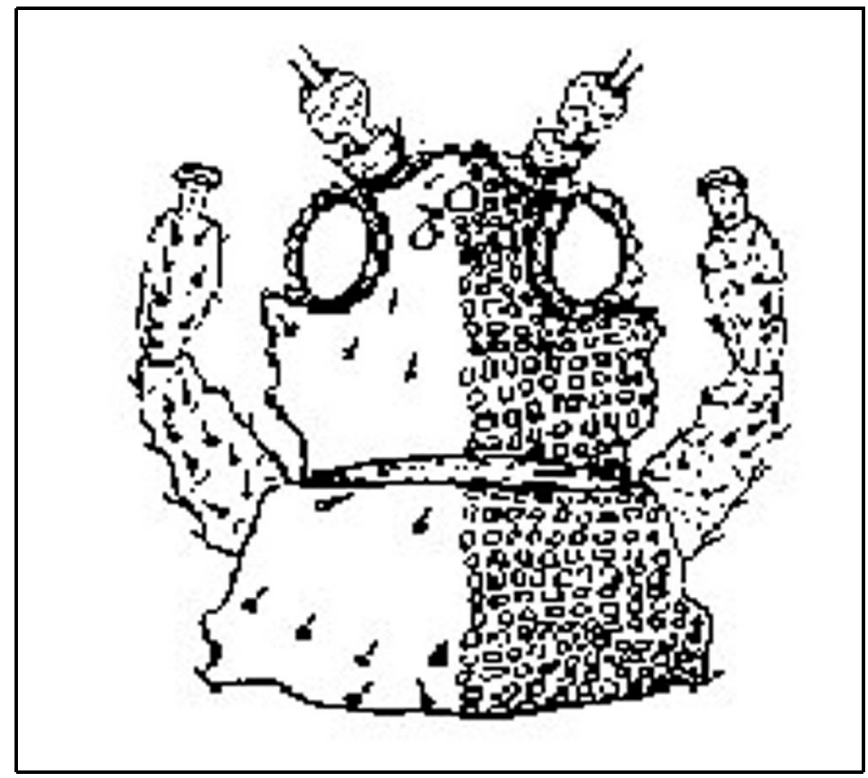

Figure 4. Head and prothorax. Credits: Division of Plant Industry

\section{Hosts}

In Florida, this thrips is found especially on crotons, but has been taken from viburnum, dogwood, azalea, Vitis sp., palms, ardisia, orchids, avocado, philodendron, Crinum sp., Ficus nitida, natal plum, Coleus sp., maple, magnolia, mangoes, Aspidium sp., dahlias, ferns, guavas, hibiscus, phlox, pinks and many other ornamentals. In Palestine, it is reported on oranges and on Garcinia mangostana in Ceylon.

The greenhouse thrips causes rind blemish problems on developing citrus fruit (i.e., ring spotting or irregular russeting), on immature and mature clustered fruit, or where a leaf or twig is in direct contact with a fruit (Stansly et al. 2003).

\section{Economic Importance}

This thrips feeds primarily on the foliage of ornamental plants. It attacks the lower surface first and, as feeding progresses and the population increases, the thrips move to the upper surface. The leaves become discolored and develop a distorted aspect between the lateral veins. Severely damaged 
leaves turn yellow and drop. In addition to the feeding damage, both surfaces are covered with small droplets of a reddish fluid, voided by the thrips, that gradually changes to black. These globules of fluid increase in size until they fall off and another one begins to form, resulting in a characteristic spotting of the infestation area with black specks of fecal material. The globules serve as deterrents to predators (Anonymous 2003).

In Palestine, the greenhouse thrips injures the leaves and fruit of citrus, but does not cause leaf drop. The damage of the fruit may be well defined depressed areas, often with irregular reticulation. This kind of damage occurs when fruit is immature. On mature fruit this damage is not well defined and merges into the healthy peel without a depression. In California, based on past data, the greenhouse thrips is of greatest economic importance on coastal avocados (Anonymous 2003).

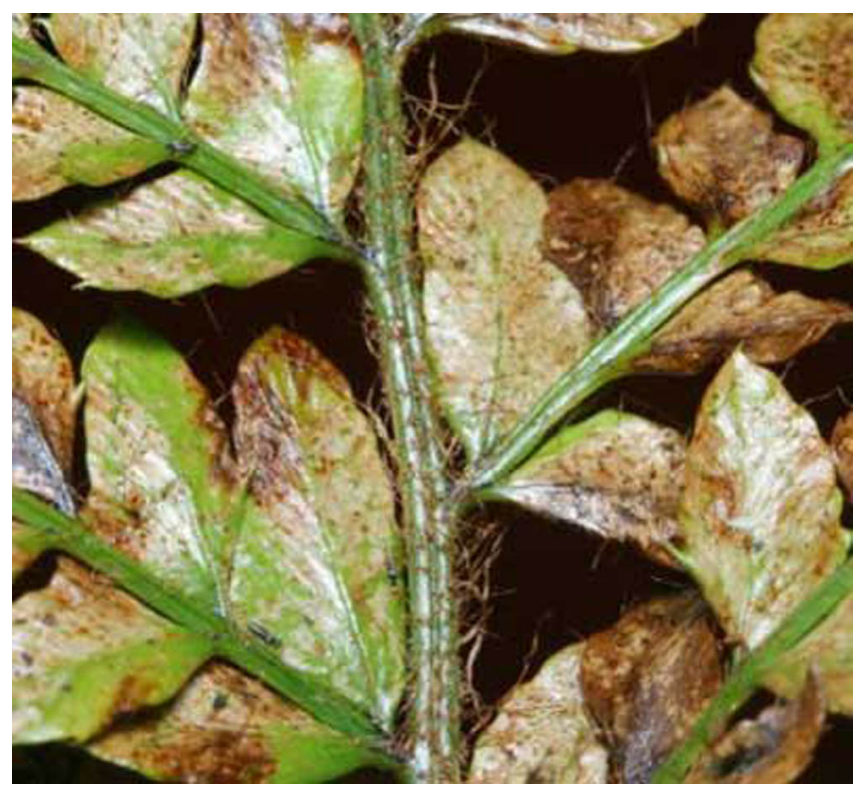

Figure 5. Damage produced by greenhouse thrips, Heliothrips haemorrhoidalis (Bouché), feeding on wood fern. Credits: Mike Merchant, Texas Cooperative Extension Service

\section{Management}

Only one effective natural enemy is known to attack greenhouse thrips. The minute larval parasite Thripobius semiluteus, which was introduced into California from Brazil and Australia in the mid-1980s. Parasitized thrips larvae appear swollen and the sides of their body are more parallel than tapered as in the case of healthy thrips larvae. The immobile parasite pupae appear black among the colonies of translucent, unparasitized thrips.

Other less effective natural enemies include an egg parasite, Megaphragma mymaripenne, and three predatory thrips species, Franklinothrips orizabensis, F. vespiformis, and Leptothrips mali, also known as the black hunter.(Anonymous 2003).

Current Florida management recommendations may be found at:

- Insect Management Guide for Ornmentals (http://edis.ifas.ufl.edu/TOPIC_GUIDE_IG_ Ornamentals).

- Citrus Pest Management Guide for Thrips (http://edis.ifas.ufl.edu/CG005).

\section{Selected References}

Anonymous. (2003). Greenhouse thrips. How to Manage Pests: UC Pest Management Guidelines. http://axp.ipm.ucdavis.edu/PMG/r107301811.html (18 August 2004).

Funderburk J, Stavisky J, Olson S, Momol T. (2000). Thrips biology and management. http://thrips.ifas.ufl.edu/Background.htm (17 August 2004).

Short, DE,Mizell RF, and Fasulo TR. (1998). Woodybug: A knowledgebase of pest and beneficial arthropods of Florida woody ornamentals. UF/IFAS. SW-119.

Stansly PA, Childers CC, Nigg HN, Simpson SE. (2003). Florida Citrus Pest Management Guide: plant bugs, chewing insect pests, Caribbean fruit fly, and thrips. http://edis.ifas.ufl.edu/CG005 (18 August 2004). 